\title{
Oxoaporphine alkaloids from the barks of Platymitra siamensis Craib (Annonaceae) and their cytotoxicity against MCF-7 cancer cell line
}

\author{
Shieh Ting KAN 1 (D), Mohamad Syahrizal AHMAD ${ }^{1 *}$ (D), Saripah Salbiah SYED ABDUL AZZIZ1 (D), \\ Khalijah AWANG ${ }^{2}$ (D), Yuhanis MHD BAKRI ${ }^{1}$ D, Mohd Azlan NAFIAH ${ }^{1}$ (D), Phirdaous ABBAS ${ }^{3}$ (D), \\ Yumi Zuhanis Has-Yun HASHIM 3,4 (D) \\ 1 Department of Chemistry, Faculty of Science and Mathematics, Sultan Idris Education University, 35900 Tanjong \\ Malim, Perak Darul Ridzuan, Malaysia. \\ 2 Department of Chemistry, Faculty of Science, University of Malaya, 50603 Kuala Lumpur, Malaysia. \\ 3 Department of Biotechnology Engineering, Kulliyyah of Engineering, International Islamic University of Malaysia, \\ P.O. Box 10, 50728 Kuala Lumpur, Malaysia. \\ 4 International Institute for Halal Research and Training, International Islamic University of Malaysia, P.O. Box 10, \\ 50728 Kuala Lumpur, Malaysia. \\ * Corresponding author. E-mail: syahrizal@fsmt.upsi.edu.my (M.S.A.); Tel +6015-48797346; Fax +605-4583616.
}

Received: 05 January 2018 / Revised: 04 June 2018 / Accepted: 29 June 2018

ABSTRACT: Study on the chemical constituents of the dichloromethane (DCM) crude extract of Platymitra siamensis Craib has led to the isolation of four oxoaporphine alkaloids. The compounds were identified as liriodenine (1), Omethylmoschatoline (2), lysicamine (3) and cepharadione-A (4) which were isolated first time from this species. The structures of the isolated compounds were elucidated based on their spectral data $\left({ }^{1} \mathrm{H},{ }^{13} \mathrm{C}\right.$ and LCMS) and reports in the literature. Here we observed that, only alkaloid 1 exhibited obvious cytotoxic effects against MCF-7 human breast cancer cells line with $\mathrm{IC}_{50}$ value of $31.26 \mu \mathrm{M}$. This work is the first attempt on phytochemical and bioactivity study on the genus of Platymitra.

KEYWORDS: Platymitra siamensis ; Annonaceae ; oxoaporphine alkaloids ; MCF-7 ; cytotoxic activity.

\section{INTRODUCTION}

Annonaceae is the largest flowering plant family in Magnoliales. There are 109 validly described and recognized genera and 2440 species in this family [1,2]. Annonaceae is also the most species-rich family in the order of Magnoliales [3]. However, the Platymitra is a very small genus that belongs to Annonaceae with only two species recognised. According to The Plant List, there are 3 species recorded. P. arborea is the only accepted name among the species in the genus Platymitra in Annonaceae family while the P. siamensis and P. macrocarpa are still in unresolved status [4]. On the other hand, botany wikispaces stated that P. siamensis (syn $P$. macrocarpa) is an abundant and important tree in Mainland Southeast Asia, and while P. arborea is often found abundantly in evergreen forests of the surrounding region of Thailand, Sumatra, Java and the Philippines [5].

The vernacular name of $P$. siamensis Craib in Malaysia is "mangitan" [6]. As stated by Whitmore, this species is rare and scattered in lowland forest, typically on hillsides [7]. In Malaysia, it can be found in several areas namely Langkawi, Kedah, Perak, Selangor, Negeri Sembilan and Johor. P. siamensis Craib can grow up to $12 \mathrm{~m}$ and $14 \mathrm{~cm}$ in diameter. The outer stem barks normally are grey or darkish grey in colour with irregular cracking but pale brown inner. The leaves are alternate simple, thinly coriaceous and $10-16 \mathrm{~cm} \times 3.0-4.5 \mathrm{~cm}$ in size. Besides that, the leaves are shining dark green on the upside surface but paler for the downside.

In terms of its application, this species is an indigenous plant that has been reported to be widely used for interior construction, ship and boat building, furniture, agricultural implements and some ornaments [68]. Although Annonaceae family is well known to have numerous bioactive chemical compounds particularly alkaloids but, to date, there have been no reports on P. siamensis Craib chemistry and bioactivities [9]. Bioactive

\footnotetext{
How to cite this article: Kan ST, Ahmad MS, Syed Abdul Aziz SS, Awang K, Mhd Bakri Y, Nafiah MA, Abbas P, Hashim YZHY. Oxoaporphine alkaloids from the barks of Platymitra siamensis Craib (Annonaceae) and their cytotoxicity against MCF-7 cancer cell line. J Res Pharm. 2019; 23(2): 217223.
} 
compounds from plants have been reported to exert anti-cancer activities with minimal side effects, as such search into these alternative natural resources including from genus Platymitra is important and timely.

This current study is the first attempt to isolate alkaloids from the barks of $P$. siamensis Craib and investigate its cytotoxicity activity against MCF-7 breast cancer cell lines. Breast cancer is the most common cancer in woman worldwide. According to the latest available data from GLOBOCAN, breast cancer is listed as the fifth cause of death from cancer overall (522,000 deaths; $25 \%$ of all cancers) with an estimated 1.67 million new breast cancer cases diagnosed in 2012 [10]. MCF-7 cells represent a very important candidate in research of breast cancer [11]. It is an ER-positive and progesterone receptor (PR)-positive [12], less aggressive and noninvasive cell line [13].

Liriodenine, was identified of having antimicrobial, antibiotic, antifungal, antitumor, cardiovascular effects and antiplatelet properties and actions [14]. In this study, four alkaloids were isolated and identified as liriodenine (1), O-methylmoschatoline (2), lysicamine (3) and cepharadione-A (4) (Figure 1). All compounds were isolated for the first time from Platymitra genus. The structures of the compounds were identified based on the spectroscopic data and comparison with literature.<smiles>O=C1c2ccccc2-c2c3c(cc4ccnc1c24)OCO3</smiles>

1<smiles>COc1cc2ccnc3c2c(c1OC)-c1ccccc1C3=O</smiles>

3<smiles>COc1c(OC)c2c3c(nccc3c1OC)C(=O)c1ccccc1-2</smiles>

2<smiles>CN1C(=O)C(=O)c2cc3c(c4c2c1cc1ccccc14)OCO3</smiles>

4

Figure 1. Chemical structures of $\mathbf{1} \mathbf{- 4}$ isolated from P. siamensis Craib.

\section{RESULTS AND DISCUSSION}

\subsection{Structural Elucidation}

Compound 1 was isolated for the first time from Liriodendron tulipifera L., and followed by other plant species [15]. Most are found in the families of Magnoliaceae, Annonaceae, Rutaceae, Monimiaceae, and Menispermaceae [14]. This compound was obtained as yellow needles. The MS analysis exhibited a molecular ion peak at $\mathrm{m} / z 275.1[\mathrm{M}]^{+}$, suggesting the molecular formula $\mathrm{C}_{17} \mathrm{H}_{9} \mathrm{NO}_{3}$. The ${ }^{1} \mathrm{H} \mathrm{NMR}$ spectrum $\left(\mathrm{CDCl}_{3}, 500\right.$ $\mathrm{MHz}$ ) of 1 showed two protons singlet at $\delta 6.36$ corresponding to the presence of methylenedioxy group, $\mathrm{OCH}_{2} \mathrm{O}$. Meanwhile a proton singlet at $\delta 7.14$ belonged to H-3. Two sets of one proton doublet at $\delta 7.74$ and $\delta$ 8.86 represent $\mathrm{H}-4$ and $\mathrm{H}-5$, respectively. Two set of double of doublets at $\delta 8.55$ and $\delta 8.59$ were attributable to $\mathrm{H}-8$ and $\mathrm{H}-11$, respectively. In addition, two sets of one proton triplet of doublets at $\delta 7.55$ and $\delta 7.72$ were assigned to $\mathrm{H}-9$ and $\mathrm{H}-10$, respectively. The ${ }^{13} \mathrm{C}$ NMR spectrum of $\mathbf{1}$ exhibited seventeen signals. The spectrum indicated the presence of one methylene, seven methine and eight quartenary carbons and one carbonyl 
carbon. Signal at $\delta 182.4$ indicated the carbonyl carbon while signal $\delta 102.6$ attributed to the methylenedioxy carbon. These spectroscopic properties were similar to those of the known compound liriodenine.

Compound 2 was obtained as orange yellowish needles. The MS spectrum revealed a strong molecular ion peak at $\mathrm{m} / \mathrm{z} 321.1[\mathrm{M}]^{+}$, thus providing the possibility of the molecular formula to be $\mathrm{C}_{19} \mathrm{H}_{15} \mathrm{NO}_{4}$. The ${ }^{1} \mathrm{H}$ NMR $\left(500 \mathrm{MHz}, \mathrm{CDCl}_{3}\right)$ of compound $\mathbf{2}$ showed similarity to that of $\mathbf{1}$ indicating that $\mathbf{2}$ also is an oxoaporphine alkaloid. However, the spectrum of $\mathbf{2}$ did not contain signals arising from methylenedioxy group $\left(\mathrm{O}-\mathrm{CH}_{2}-\mathrm{O}\right)$, instead it displayed three methoxy signals at $\delta 4.08, \delta 4.11$ and $\delta 4.19$. Therefore these three methoxyl carbons suggested to be located at C-1, C-2 and C-3, respectively. The ${ }^{13} \mathrm{C}$ NMR spectrum supported the structure of compound 2. Three methoxyl carbons appeared at $\delta 61.1, \delta 61.6$ and $\delta 61.9$ belong to $\mathrm{OCH}_{3}-1, \mathrm{OCH}_{3}-2$ and $\mathrm{OCH}_{3}-3$, respectively. The carbonyl carbon signal appeared at $\delta 182.7$ and no signal was found at $\delta 100.2$, thus suggesting that the methylenedioxy carbon was replaced with two methoxyl carbons. These spectroscopic data were similar to those of the known compound $O$-methylmoschatoline; which has been reported to be isolated from two species of Annonaceae namely Ellipeia cuneifolia [16] and Annona foetida Mart [17].

Compound 3 was obtained as yellowish amorphous. The MS spectrum revealed a strong molecular ion peak at $\mathrm{m} / z 291.1[\mathrm{M}]^{+}$, thus providing the possibility of the molecular formula to be $\mathrm{C}_{18} \mathrm{H}_{13} \mathrm{NO}_{3}$. The ${ }^{1} \mathrm{H}$ NMR $\left(500 \mathrm{MHz}, \mathrm{CDCl}_{3}\right)$ of compound 3 showed similar pattern with compound 2 due to the presence of two methoxyl signals at $\delta 4.02$ and $\delta 4.11$. There are one proton singlet $\mathrm{H}-3$ at $\delta 7.24$, two triplets of proton $\mathrm{H}-9$ and $\mathrm{H}-10$ (appearing at $\delta 7.58$ and $\delta 7.79$ respectively), two doublets of aromatic protons ( $\mathrm{H}-4$ and $\mathrm{H}-5$ revealing separately at $\delta 7.81$ and $\delta 8.89$ ) and another two double of doublets signals of aromatic protons (assigned to $\mathrm{H}-8$, at $\delta 8.60$ and $\mathrm{H}-11$ at $\delta 9.20$ ). The ${ }^{13} \mathrm{C}-\mathrm{NMR}$ spectrum showed eighteen carbon signals, including one carbonyl carbon resonated at $\delta 182.9$ assigned to C-7. Two methoxyl carbons appeared at $\delta 56.3$ and $\delta 60.8$ were appointed to $\mathrm{OCH}_{3}-1$ and $\mathrm{OCH}_{3}-2$, respectively. In addition, seven methine aromatic carbons resonated at $\delta 106.5, \delta 123.7, \delta 145.2, \delta 129.0, \delta 128.9, \delta 134.4$ and $\delta 128.5$ were designated to C-3, C-4, C-5, C-8, C-9, C-10 and C-11, respectively. Eight quaternary carbons assigned as C-1, C-1a, C-2, C-3a, C-3b, C-6a, C-7a and C-11a were identified at chemical shifts of $\delta 156.9, \delta 120.0, \delta 152.1, \delta 135.6, \delta 122.3, \delta 145.5, \delta 132.2$ and $\delta 134.5$, respectively. This compound has been reported to be previously isolated from leaves of Phoebe grandis (Nees) Merr. (Lauraceae) [18] and Xylopia aethiopica (Annonaceae) [19].

Compound 4 was obtained as orange amorphous. The MS spectrum revealed a strong molecular ion peak at $m / z 305.2[\mathrm{M}]^{+}$, thus providing the possibility of the molecular formula to be $\mathrm{C}_{18} \mathrm{H}_{11} \mathrm{NO}_{4}$. The ${ }^{1} \mathrm{H}$ NMR $\left(500 \mathrm{MHz}, \mathrm{CDCl}_{3}\right)$ of compound 4 showed the presence of one $N$-methyl and one methylenedioxy group, $\mathrm{OCH}_{2} \mathrm{O}$ with the singlets at $\delta 3.86$ and $\delta 6.46$, respectively. Two singlets appearing at $\delta 8.14$ and $\delta 7.52$ were assigned to shielded hydrogen atoms placed at C-3 and C-7. The aromatic protons revealed two double of doublets at $\delta 9.00$ and $\delta 7.90$ (assigned to $\mathrm{H}-11$ and $\mathrm{H}-8$, respectively) and two protons represented by multiplets at $\delta$ 7.69-7.71 (assigned to $\mathrm{H}-9$ and $\mathrm{H}-10$ ). The ${ }^{13} \mathrm{C}$ NMR spectrum of 4 exhibited eighteen signals. The spectrum indicated the presence of six methines at $\delta 109.0, \delta 114.9, \delta 128.4, \delta 127.7, \delta 126.8$ and $\delta 128.4$ which are assigned to C-3, C-7, C-8, C-9, C-10 and C-11, respectively. Signal at $\delta 174.6$ and $\delta 157.5$ indicated the carbonyl carbons which are located at C-4 and C-5 while signal at $\delta 103.8$ attributed to the methylenedioxy group. These spectroscopic properties were similar to those of the known compound cepharadione-A; previously isolated from roots of two species of Piperaceae; Piper nigrum [20] and Piper betle Linn [21]. The analysis of 1D NMR spectra data of compounds 1, 2, 3 and $\mathbf{4}$ were tabulated in Table 1 together with the sources of the references [22-24].

\subsection{BIOACTIVITY}

The anticancer activity of the crude extracts of dicholoromethane (DCM), hexane and methanol $(\mathrm{MeOH})$; and four pure alkaloids from $P$. siamensis Craib were tested against MCF-7 human breast cancer cells. At the concentration tested $(0-40 \mu \mathrm{M})$, crude extracts did not possess cytotoxic or anticancer effects against MCF-7 breast cancer cells. Meanwhile, pure compounds 1 exhibited $\mathrm{IC}_{50}$ value of $31.26 \mu \mathrm{M}$ (Figure 2). However, compound 2, 3 and 4 did not show any inhibition on MCF-7 cells at concentration tested. Compound 1, liriodenine has been reported to have anticancer effects against several types of cancer targeting at various pathways including apoptosis and cell cycle arrest without exerting cytotoxic effects to normal cells [25-27]. 
Table 1. ${ }^{1} \mathrm{H}-\mathrm{NMR}$ and ${ }^{13} \mathrm{C}-\mathrm{NMR}$ spectroscopic data $\left(\mathrm{CDCl}_{3}\right)$ of compound 1, 2, 3 and 4.

\begin{tabular}{|c|c|c|c|c|c|c|c|c|}
\hline \multirow[b]{2}{*}{ Position } & \multicolumn{2}{|c|}{ Compound $1[22,23]$} & \multicolumn{2}{|c|}{ Compound 2 [16] } & \multicolumn{2}{|c|}{ Compound 3 [18] } & \multicolumn{2}{|c|}{ Compound 4 [24] } \\
\hline & $\begin{array}{c}\delta^{13} \mathrm{C} \\
(\mathrm{ppm})\end{array}$ & $\begin{array}{c}\delta^{1} \mathbf{H}(\mathbf{p p m}) \\
J(\mathrm{~Hz})\end{array}$ & $\begin{array}{c}\delta^{13} \mathrm{C} \\
(\mathrm{ppm})\end{array}$ & $\begin{array}{c}\delta^{1} \mathbf{H}(\mathrm{ppm}) \\
J(\mathrm{~Hz})\end{array}$ & $\begin{array}{c}\delta^{13} \mathrm{C} \\
(\mathrm{ppm})\end{array}$ & $\begin{array}{c}\delta^{1} \mathbf{H}(\mathrm{ppm}) \\
J(\mathrm{~Hz})\end{array}$ & $\delta^{13} C(p p m)$ & $\begin{array}{c}\delta^{1} \mathbf{H}(\mathrm{ppm}) \\
J(\mathrm{~Hz})\end{array}$ \\
\hline $\mathrm{O}-\mathrm{CH}_{2}-\mathrm{O}$ & 102.6 & $6.36(s)$ & - & - & - & - & 103.8 & $6.46(s)$ \\
\hline 1 & 148.1 & - & 156.6 & - & 156.9 & - & 152.0 & - \\
\hline $1 \mathrm{a}$ & & - & 115.7 & - & 120.0 & - & - & - \\
\hline 2 & 151.9 & - & 147.4 & - & 152.1 & - & 148.3 & - \\
\hline 3 & 103.3 & $7.14(s)$ & 148.5 & - & 106.5 & $7.24(s)$ & 109.0 & $8.14(s)$ \\
\hline $3 a$ & 135.9 & - & 122.9 & - & 135.6 & - & 125.4 & - \\
\hline $3 b$ & & - & 131.2 & - & 122.3 & - & - & - \\
\hline 4 & 124.4 & $\begin{array}{c}7.74(d) \\
J=5.7\end{array}$ & 119.3 & $\begin{array}{c}8.24(d) \\
J=5.2\end{array}$ & 123.7 & $\begin{array}{c}7.81(d) \\
J=5.0\end{array}$ & 174.6 & - \\
\hline 5 & 144.8 & $\begin{array}{c}8.86(d) \\
J=5.5\end{array}$ & 144.5 & $\begin{array}{c}8.98(d) \\
J=5.8\end{array}$ & 145.2 & $\begin{array}{c}8.89(d) J= \\
5.0\end{array}$ & 157.5 & - \\
\hline $6 a$ & 145.2 & - & 145.5 & - & 145.5 & - & 131.8 & - \\
\hline $6 b$ & 123.3 & - & - & - & - & - & - & - \\
\hline 7 & 182.4 & - & 182.7 & - & 182.9 & - & 114.9 & $7.52(s)$ \\
\hline $7 a$ & 131.2 & - & 131.5 & - & 132.2 & - & 129.1 & - \\
\hline 8 & 128.8 & $\begin{array}{l}8.55(d d) \\
J=8.0,0.6\end{array}$ & 129.0 & $\begin{array}{c}8.59(d) \\
J=8.3\end{array}$ & 129.0 & $\begin{array}{l}8.60(d d) \\
J=7.6,0.7\end{array}$ & 128.4 & $\begin{array}{l}7.90(d d) \\
J=8.0,0.6\end{array}$ \\
\hline 9 & 128.7 & $\begin{array}{l}7.55(t d) \\
J=7.5,0.6\end{array}$ & 128.2 & $\begin{array}{l}7.55(d t) \\
J=6.9,7.5\end{array}$ & 128.9 & $7.58(t)$ & 127.7 & $\begin{array}{c}7.69-7.71 \\
(m)\end{array}$ \\
\hline 10 & 134.0 & $\begin{array}{l}7.72(t d) \\
J=8.1,0.6\end{array}$ & 134.5 & $\begin{array}{l}7.76(d t) \\
J=9.2,6.9\end{array}$ & 134.4 & $7.79(t)$ & 126.8 & $\begin{array}{l}7.69-7.71 \\
(m)\end{array}$ \\
\hline 11 & 127.4 & $\begin{array}{l}8.59(d d) \\
J=8.1,0.6\end{array}$ & 127.7 & $\begin{array}{c}9.13(d) \\
J=8.6\end{array}$ & 128.5 & $\begin{array}{c}9.20(d d) J= \\
7.6,0.7\end{array}$ & 128.4 & $\begin{array}{l}9.00(d d) \\
J=8.0,0.6\end{array}$ \\
\hline $11 a$ & 132.9 & - & 134.6 & - & 134.5 & - & 127.7 & - \\
\hline $11 b$ & 108.1 & - & - & - & - & - & 116.0 & - \\
\hline $\mathrm{OCH}_{3}-1$ & - & - & 61.1 & $4.08(s)$ & 56.3 & $4.02(s)$ & - & - \\
\hline $\mathrm{OCH}_{3}-2$ & - & - & 61.6 & $4.11(s)$ & 60.7 & $4.11(s)$ & - & - \\
\hline $\mathrm{OCH}_{3}-3$ & - & - & 61.9 & $4.19(s)$ & - & - & - & - \\
\hline $\mathrm{N}-\mathrm{CH}_{3}$ & - & - & - & - & - & - & 30.0 & $3.86(s)$ \\
\hline
\end{tabular}

\section{CONCLUSION}

In conclusion, four oxoaporphine alkaloids were isolated from DCM crude extract of $P$. siamensis Craib barks. Compound 1, was found to be active at inhibiting MCF-7 breast cancer cell growth and this warrants further investigation. More new alkaloids are expected to be found in P. siamensis Craib since this species has not been studied before. 


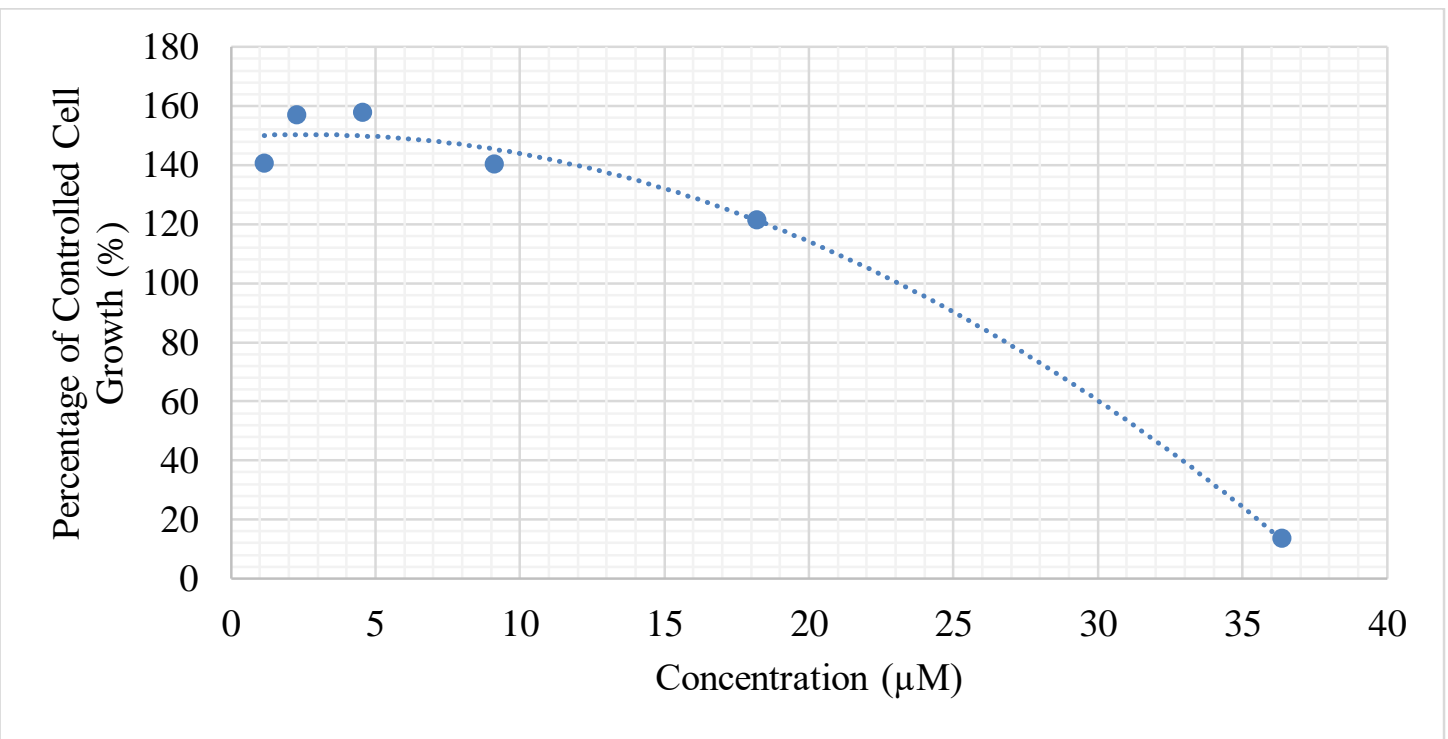

Figure 2. Percentage of Controlled Cell Growth (PCCG) vs concentration plot for pure compound 1. IC 50 value of $31.26 \mu \mathrm{M}$ was obtained for compound $\mathbf{1}$.

\section{MATERIALS AND METHODS}

\subsection{General experimental procedure}

Analytical grade reagents and chemicals were used unless otherwise stated. DCM and $\mathrm{MeOH}$ were obtained from Systerm ${ }^{\circledR}$. Hexane was purchased from $\mathrm{HmbG}^{\circledR}$ Chemicals and $\mathrm{CDCl}_{3}$ were obtained from ACROS $^{\circledR}$ Organics. MCF-7 human breast cancer cells were purchased from American Type Culture Collection (ATCC ${ }^{\circledR}$ HTB-22 ${ }^{\mathrm{TM}}$ ). The IR spectra were carried out on the Thermo Nicolet FTIR model 6700 spectrophotometer. Meanwhile, the mass spectra were recorded on Agilent Technologies GCMS-5975C VL MSD Spectrometer (USA). The UV-Vis spectra were carried out using UV-Vis spectrophotometer model Agilent Cary 60 and the NMR spectra were performed using JEOL JNM-ECX (500 MHz). Silica gel 60, 200 400 mesh was used for column chromatography (CC). The TLC plates were pre-coated with aluminium supported silica gel $60 \mathrm{~F}_{254}$ from Merck, observed under UV light (254 nm and $\left.365 \mathrm{~nm}\right)$ model UVGL-58 and followed by spraying with Dragendorff's reagent to determine the presence of alkaloids.

\subsection{Plant material}

Barks of $P$. siamensis Craib with herbarium number KL 5753 was identified and collected by phytochemical group of Chemistry Department, University of Malaya, Kuala Lumpur from Hutan Simpan Sungai Badak, Jitra, Kedah in Malaysia on 7th October 2010. The voucher specimen was deposited at Chemistry Department, University of Malaya, Kuala Lumpur.

\subsection{Extraction and Isolation}

Cold maceration technique was used in this work. The dried and powdered bark ( $1800 \mathrm{~g})$ of P. siamensis Craib was defatted with hexane for $72 \mathrm{~h}$ at room temperature to give hexane extract $(7.8 \mathrm{~g}, 0.0043 \%)$. After drying for $24 \mathrm{~h}$, the sample was moistened with $40 \%$ of ammonia $\left(\mathrm{NH}_{3}\right)$ solution for $3 \mathrm{~h}$ before being submitted for another extraction using DCM for $72 \mathrm{~h}$. The sample was then filtrated and concentrated to yield DCM extract $(8.8 \mathrm{~g}, 0.0049 \%)$. About $1.2 \mathrm{~g}$ of DCM extract was kept for bioactivity and the remaining (about $7.6 \mathrm{~g}$ ) was chromatographed on silica gel CC using DCM/MeOH (100:0 to 0:100, v/v) to yield 229 fractions with 50 $\mathrm{mL}$ each. These fractions were evaluated and pooled according to TLC analysis yielding 57 fractions (P1-P57). Fractions P17-P22 were subjected to CC on silica gel using solvent system of DCM/MeOH (100:0 to 99:1) and gave 15 fractions. The sub-fractions 3-6 gave liriodenine (1) $(7.5 \mathrm{mg}, 0.00042 \%)$. The sub-fractions $10-13$ gave cepharadione-A (4) (2.9 mg, 0.00016\%). Fractions P30-P35 were subjected to CC on silica gel using solvent system of $\mathrm{DCM} / \mathrm{MeOH}$ (100:0 to 98:2) and gave 27 fractions. The sub-fractions 8-11 gave $O$ methylmoschatoline (2) $(2.7 \mathrm{mg}, 0.00015 \%)$ while the sub-fractions $17-22$ were subjected to microcolumn on silica gel using solvent system of $\mathrm{DCM} / \mathrm{MeOH}$ (99.5:0.5 to 98:2) and produced 11 fractions. The fractions 2-6 produced lysicamine (3) $(1.9 \mathrm{mg}, 0.00011 \%)$. 


\subsection{Cell line and culture medium}

MCF-7 human breast cancer cells were thawed from liquid nitrogen storage and cultured in growth medium (Dulbecco's modified eagle's medium, DMEM) with 10\% (v/v) fetal bovine serum (FBS). For cell viability assay, cells were detached, counted using trypan blue dye exclusion method, and seeded into 96-well flat bottom tissue culture plate. Seeding concentration was set at $1 \times 10^{5}$ cells $/ \mathrm{mL}$ and cells were allowed to propagate for $24 \mathrm{~h}$ before introduction of samples to the growth medium. After $24 \mathrm{~h}$ of growth, $10 \mu \mathrm{L}$ of SAS was pipetted into each designated well and the plate was incubated for $48 \mathrm{~h}$. Then, $10 \mu \mathrm{L}$ of CCK-8/WST8/Cell Counting Kit-8 reagent was added and the plate was further incubated for $1 \mathrm{~h}$. After $1 \mathrm{~h}$, optical density (OD) reading was measured at $450 \mathrm{~nm}$ wavelength. The assay was carried out in three independent experiments. $\mathrm{IC}_{50}$ value (concentration of compound that yields $50 \%$ less cells compared to the control) was derived from curve-fitting methods. OD data was used to plot the dose-response between the compound concentration and growth inhibition percentage. The percentage of the controlled cell growth (PCCG) is determined as follows:

$$
P C C G=\left(\frac{O D_{\text {sample }}-O D_{\text {blank }}}{O D_{\text {negative control }}-O D_{\text {blank }}}\right) \times 100 \%
$$

Acknowledgement: Our acknowledgement to Sultan Idris Education University and Ministry of Higher Education (MOHE), Malaysia for provision of financial support for this research work (GPU: 2016-0055-101-01) and (FRGS: 20140030-101-02), respectively.

Author contributions: Concept - M.S.A., S.S.S.A.A.; Design - M.S.A., S.S.S.A.A., Y.Z.H.H.; Supervision - M.S.A., S.S.S.A.A., K.A., Y.M.B., M.A.N., Y.Z.H.H.; Resource - S.S.S.A.A., K.A., Y.Z.H.H.; Materials - M.S.A., S.S.S.A.A., Y.M.B., Y.Z.H.H.; Data Collection and/or Processing - K.S.T., P.A.; Analysis and/or Interpretation - M.S.A., S.S.S.A.A., Y.M.B., M.A.N., Y.Z.H.H.; Literature Search - K.S.T., P.A.; Writing - M.S.A., K.S.T., S.S.S.A.A., P.A., Y.Z.H.H.; Critical Reviews - M.S.A., K.S.T., S.S.S.A.A., K.A., Y.M.B., M.A.N., P.A., Y.Z.H.H.

Conflict of interest statement: The authors declare that there is no conflict of interest in this research.

\section{REFERENCES}

[1] Wiart C, Medicinal Plants of the Asia-Pasific: Drugs for the Future?, World Scientific Publishing Co. Pte. Ltd., Singapore 2006.

[2] Chatrou LW, Pirie MD, Erkens RHJ, Couvreur TLP, Neubig KM, Abbott JR, Mols JB, Maas JW, Saunders RMK, Chase MW. A new subfamilial and tribal classification of the pantropical flowering plant family Annonaceae informed by molecular phylogenetics. Bot J Linn Soc. 2012; 169(1): 5-40. [CrossRef]

[3] Sauquet H, Doyle JA, Scharaschkin T, Borsch T, Hilu KW, Chatrou LW, Thomas AL. Phylogenetic analysis of Magnoliales and Myristicaceae based on multiple data sets: Implications for character evolution. Bot J Linn Soc. 2003; 142(2): 125-186. [CrossRef]

[4] The Plant List. http://www.theplantlist.org/ (accessed September 17, 2017).

[5] XTBG-Botany. http://xtbg-botany.wikispaces.com/ (accessed August 01, 2017).

[6] Priyadi H, Takao G, Rahmawati I, Supriyanto B, Ikbal Nursal W, Rahman I. Five hundred plant species in Gunung Halimun Salak National Park, West Java: A checklist including Sundanese names, distribution and use. CIFOR, Bogor, Indonesia 2010.

[7] Whitmore TC, Tree flora of Malaya: a manual for forester, first ed., Longman, London 1972.

[8] Hong LT, Lemmens RHMJ, Prawirohatmodjo S, Soerianegara I, Sosef MSM, Wong WC, Plant resources of South East Asia: Timber trees, first ed., Springer-Verlag Berlin Heidelberg, Netherlands 1999.

[9] Lúcio ASSC, Almeida JRGS, da-Cunha EVL, Tavares JF, Filho JMB. Chapter Five-Alkaloids of the Annonaceae: Occurrence and a compilation of their biological activities. In: Knolker HJ. (Eds). The Alkaloids: Chemistry and Biology. Elsevier, Inc., New York, 2015, pp. 233-409.

[10] GLOBOCAN. http://globocan.iarc.fr/Pages/fact_sheets_cancer.aspx (accessed April 11, 2018). 
[11] Baguley BC, Leung E. Heterogeneity of phenotype in breast cancer cell lines. In: Gunduz M, Gunduz E. (Eds). Breast Cancer - Carcinogenesis, Cell Growth and Signalling Pathways. InTech Open Ltd., United Kingdom, 2011, pp. 245256.

[12] Shirazi FH. Remarks in successful cellular investigations for fighting breast cancer using novel synthetic compounds. In: Gunduz M, Gunduz E. (Eds). Breast Cancer - Focusing Tumor Microenvironment, Stem Cells and Metastasis. InTech Open Ltd., United Kingdom, 2011, pp. 85-102.

[13] Gest C, Joimel U, Huang L, Pritchard LL, Petit A, Dulong C, Buquet C, Hu CQ, Mirshahi P, Laurent M, Fauvel-Lafève F, Cazin L, Vannier JP, Lu H, Soria J, Li H, Varin R, Soria C. Rac3 induces a molecular pathway triggering breast cancer cell aggressiveness: differences in MDA-MB-231 and MCF-7 breast cancer cell lines. BMC Cancer. 2013; 13: 6372. [CrossRef]

[14] Chen CY, Wu HM, Chao WY, Lee CH. Review on pharmacological activities of liriodenine. Afr J Pharm Pharmacol. 2013; 7(18): 1067-1070. [CrossRef]

[15] Warthen D, Gooden EL, Jacobson M. Tumor inhibitors: Liriodenine, a cytotoxic alkaloid from Annona glabra. J Pharm Sci. 1969; 58(5): 637-638. [CrossRef]

[16] Yusof H, Din LB, Yaacob WA, Ibrahim N, Yamin BM, Latiff A. The chemical constituents of Ellipeia cuneifolia and their antibacterial activity. Sains Malays. 2015; 44(8): 1125-1128. [CrossRef]

[17] Costa EV, Pinheiro ML, de Souza AD, Barison A, Campos FR, Valdez RH, Ueda-Nakamura T, Filho BP, Nakamura $\mathrm{CV}$. Trypanocidal Activity of oxoaporphine and pyrimidine- $\beta$-carboline alkaloids from the branches of Annona foetida Mart. (Annonaceae). Molecules. 2011; 16(11): 9714-9720. [CrossRef]

[18] Omar H, Hashim NM, Zaimi A, Nordin N, Abdelwahab SI, Azizan AH, Hadi AH, Ali HM. Aporphine alkaloids from the leaves of Phoebe grandis (Nees) Mer. (Lauraceae) and their cytotoxic and antibacterial activities. Molecules. 2013; 18(8): 8994-9009. [CrossRef]

[19] Harrigan GG, Gunatilaka AAL, Kingston DGI, Chan GW, Johnson RK. Isolation of bioactive and other oxoaporphine alkaloids from two annonaceous plants, Xylopia aethiopica and Miliusa cf. banacea. J Nat Prod. 1994; 57(1): 68-73. [CrossRef]

[20] Ee GCL, Lim CM, Lim CK, Rahmani M, Shaari K, Bong CF. Alkaloids from Piper sarmentosum and Piper nigrum. Nat Prod Res. 2009; 23(15): 1416-1423. [CrossRef]

[21] Lin CF, Hwang TL, Chien CC, Tu HY, Lay HL. A new hydroxychavicol dimer from the roots of Piper betle. Molecules. 2013; 18(3): 2563-2570. [CrossRef]

[22] Chen $\mathrm{CY}, \mathrm{Wu}$ YC, Annocherine C. A new C-a hydroxy benzylisoquinoline and other constituents from the leaves of Annona cherimola. J Chin Chem Soc. 2001; 48(6B): 1203-1206. [CrossRef]

[23] Wiart C, Ethnopharmacology of Medicinal Plants: Asia and the Pacific, Humana Press, Inc., USA 2006.

[24] Ee GCL, Lim SK, Lim CM, Dzulkefly K. Alkaloids and carboxylic acids from Piper nigrum. Asian J Chem. 2008; 20(8): 5931-5940.

[25] Habli Z, Toumieh G, Fatfat M, Rahal OM, Gali Muhtasib H. Alkaloids in the battle against cancer: Overview of molecular mechanisms. Molecules. 2017; 22(2): 250-271. [CrossRef]

[26] Li ZH, Gao J, Hu PH, Xiong JP. Anticancer effects of liriodenine on the cell growth and apoptosis of human breast cancer MCF-7 cell through the upregulation of p53 expression. Oncol Lett. 2017; 14(2): 1979-1984. [CrossRef]

[27] Liu CM, Kao CL, Wu HM, Li WJ, Huang CT, Li HT, Chen CY. Antioxidant and anticancer aporphine alkaloids from the leaves of Nelumbo nucifera Gaertn. cv. Rosa-plena. Molecules. 2014; 19(11): 17829-17838. [CrossRef] 